\title{
The perception of foreign language students toward the implementation of inclusive education
}

\author{
Cahya Kusuma Negara ${ }^{1}$, Dewa Ayu Eka Agustini ${ }^{2}$, Luh Diah Surya Adnyani, \\ 1,2,3English Language Education, Ganesha University of Education, Bali, Indonesia \\ ${ }^{1}$ cahyakusuma50@gmail.com, ${ }^{2}$ eka.agustini@undiksha.ac.id, ${ }^{3}$ surya.adnyani@undiksha.ac.id \\ *) correspondence: cahyakusuma50@gmail.com
}

\begin{abstract}
This research aimed to describe the implementation of inclusive education and identify the challenges students might have in English courses at SMK N 3 Singaraja. The research subjects were students with disabilities and regular students who studied at XI MM 2 (Multi-media). This research was a case study that used the descriptive qualitative method. The data collection was done by conducting a questionnaire and interview guide sequentially. The student's perception was measured from 3 aspects, namely perceiver, target, and social setting. The result from the questionnaire and interview was analyzed continuously and described descriptively. This research showed that students with disabilities and regular students have a good perception of inclusive education implementation. However, there were several challenges, such as lacking adaptation with inclusive classrooms, time, facilities, and special teachers. It implied that the teacher and school's staff should give examples, more chances, and more attention to the inclusive class students.
\end{abstract}

Keywords: perception; inclusive education; the student with disabilities

\section{INTRODUCTION}

Inclusive education has a unique concept in its implementation. The idea is to incorporate the regular student and the student with disabilities in the same school (Adiputra, Mujiyati, \& Hendrowati, 2019; Khan, Hashmi, \& Khanum, 2017). It means that learning is held in public schools such as Elementary School, Junior High School, and Senior High School. Inclusive education is not only placing the student with disabilities with regular students, but it also gives the same opportunity for both of the students (Avcioglu, 2017). The student with disabilities gets the same opportunity in learning and facilities as regular students. The school also provides an equal quality of education and services for disabled students and regular students.

Inclusive education also breaks the barrier of the differences between students with disabilities and regular student s. There is a space for all students to interact with the other student. Avcioglu (2017) stated that inclusive education gives students more space to build successful interactions with different people. The students with disabilities are not afraid to interact with regular student $\mathrm{s}$ in regular classes even they have differences. The students in inclusive education also learn how to accept each other in differences (Avcioglu, 2017). When regular students accept each other, they can help students with disabilities in the teaching and learning process. The character building also starts from an earlier age since the inclusive education was conducted from the Elementary school, Junior High School, and Senior High School (Ediyanto, Atika, Kawai, \& Prabowo, 2017). 
Many countries have implemented inclusive education for students. In China, improving inclusive education became the significant attention in China's educational system (Zhang, Rosen, Cheng, \& Li, 2018). In Ghana, the government has committed to providing equal education opportunities for children with disabilities by implementing inclusive education (Okyere, Aldersey, \& Lysaght, 2019). United States accepted inclusive education among the U.S general and special teachers, disability activists, and parents of children with disabilities (Tahir, Brian, \& Michael, 2019). It is supported by some legislation such as All Handicapped Children Act (EAHCA) of 1975, Americans with Disabilities Act (ADA) of 1990, No Child Left Behind (NCLB) of 2001, and Every Student Succeeds Act (ESSA) of 2015.

In Indonesia, inclusive education started with the trials in the year 1998-2001 in several Yogyakarta areas (Rasmitadila \& Tambunan, 2018). The practices were used as the starting point to know more about inclusive education in Indonesia. The purpose was to introduce inclusive education and adapt it to the school. The government also provided block grants for districts to initiate inclusive schools in 2005 (Sunardi, Maryadi, 2014). It means that the districts can participate in teacher training, distribute special equipment, or building renovation for inclusive school. The implementation was also supported by Permendikbud Nomor 70 Tabun 2009; the inclusive education for the student with special needs has the potential intelligence and or the student with special talents.

Unfortunately, there are some challenges in implementing inclusive education in Indonesia from schools, teachers, and parents. The research found that Indonesia, especially elementary school, is not yet ready to implement the inclusive class (Rasmitadila \& Tambunan, 2018). It means that the school does not implement inclusive education effectively. It also found that only several teachers could not teach students in inclusive education (Ediyanto et al., 2017). Also, the parents influenced the implementation of inclusive education. Some parents have negative perceptions regarding inclusive education (Adiputra et al., 2019).

Okyere, Aldersy, and Lysaght (2019) found that students with disabilities in Ghana faced some challenges such as corporal punishment for slow performance, victimization, and low family support. Avcioglu conducted the research (2017) found that teachers' behavior and students' acceptance significantly affect communication and inclusive class interaction. In the same year, Ediyanto, Atika, Kawai, and Prabowo (2017) found that the implementation of inclusive education in Indonesia) needs to be improved in some aspects such as facilities, teachers, learning activities, curriculum, and government efforts. Rasmitadila and Tambunan (2018) found that some elementary schools are not ready yet to become inclusive schools because of some challenges. Unfortunately, there is limited research about inclusive education that including students as active participants in research. Investigating student's perceptions can give more specific information on the implementation of inclusive education in Indonesia.

One way to maximize inclusive education is by investigating students' perceptions with disabilities and regular students. It reflects how the government should develop inclusive education in the future from students who have been previously taken apart in inclusive education (Okyere et al., 2019). Investigating students also describe how students feel included in inclusive education and examine a new and innovative way to improve inclusive education (Schwab, Sharma, \& Loreman, 2018). Therefore, it is essential to investigate students' perceptions of disabilities and regular students to maximize inclusive education implementation.

Additionally, perception' perception also describes someone's meaning about a particular thing in their environment (Robbins \& Judge, 2013). The meaning shows how 
someone's view and experience to something that they received. Some factors can influence inclusive education, such as the perceiver, object or target, and situation.

The researcher is interested in investigating inclusive education in SMK N 3 Singaraja from the students' perception regarding the information. There are two students with disabilities in SMKN 3 Singaraja. The first student is a student in grade $11^{\text {th }}$. This student is categorized with double disabilities or a person with quadriplegia (physical disabilities) and a slow learner. The second student is a student in grade $12^{\text {th }}$. This student is categorized as a deaf student, and he uses a special tool to hear any sounds. The researcher also wanted to identify the challenges that face by the student toward inclusive education. SMK N 3 Singaraja is a public school that has implemented an inclusive education system since 2015 .

\section{METHODS}

The method of this research was a qualitative descriptive method. This method enabled the researcher to describe the data in detail and provide a detailed and accurate description of the participant's experiences about a phenomenon (Sandelowski, 2010). The design of this research was a case study. A case study focuses on investigating a particular or only one topic, individual, classroom, or program (Cohen, Manion, \& Morrison, 1928). This research only investigated one student with disabilities in one school and the students' perception toward implementing inclusive education. This research was conducted in SMK N 3 Singaraja in the academic year 2019/ 2020. It is only focused on 11th grade, with one student with disabilities in the class XI MM 2 (Multimedia). There were 34 students, which consist of 1 student with disabilities and 33 general students. The researcher used a questionnaire and interview guides to collect the data. The instruments were based on Organizational Behavior by Robbins and Judge (2013), which investigated the individual, groups, and structure about the effect of implementing particular knowledge. This study used the data analysis from Miles and Huberman (1994). This theory has four stages: data collection, data reduction, data display, and conclusion (drawing/verifying) (Miles \& Huberman, 1994).

\section{RESULTS AND DISCUSSION}

\section{Student's Perception toward the Implementation of Inclusive Education}

The researcher conducted the questionnaire to all students and followed by interviewing several students. All students filled the questionnaire with 20 questions about the perception and challenges of inclusive education in English class. After conducting the questionnaire, the researcher interviewed several students by using an interview guide and audio recording. The results were shown in TABLE 1.

TABLE 1. Student's Perception toward the Implementation of Inclusive Education

\begin{tabular}{|c|c|c|}
\hline Dimension & Aspect & Result \\
\hline \multirow{8}{*}{ Perceiver } & \multirow[t]{2}{*}{ Interest } & $\begin{array}{l}\text { The existence of students with } \\
\text { disabilities }\end{array}$ \\
\hline & & Inclusive class is challenged \\
\hline & \multirow[t]{2}{*}{ Motive } & Giving more experiences \\
\hline & & Developing good Behavior \\
\hline & Attitude & $\begin{array}{l}\text { The closeness with a student with a } \\
\text { disabilities }\end{array}$ \\
\hline & Experiences & The student with disabilities' attitude \\
\hline & \multirow[t]{2}{*}{ Expectation } & Equal education for all \\
\hline & & Different attention \\
\hline
\end{tabular}


The perception of foreign language students toward the implementation of inclusive education

\begin{tabular}{|c|c|c|}
\hline \multirow[t]{3}{*}{ Object } & Novelty & Not something new for all students \\
\hline & \multirow{2}{*}{$\begin{array}{l}\text { Background of Inclusive } \\
\text { Education in Indonesia }\end{array}$} & Adaptation is a challenge \\
\hline & & Teacher's role \\
\hline \multirow[t]{5}{*}{ Situation } & \multirow[t]{2}{*}{ Time } & $\begin{array}{l}\text { The teacher spent more time with a } \\
\text { student with disabilities }\end{array}$ \\
\hline & & Repetition tends to help the students \\
\hline & \multirow[t]{2}{*}{ Work Setting } & $\begin{array}{l}\text { The facility tends to be sufficient } \\
\text { for students }\end{array}$ \\
\hline & & $\begin{array}{l}\text { The student tends to have a special } \\
\text { teacher }\end{array}$ \\
\hline & Social Setting & $\begin{array}{l}\text { Not all students respect the student with } \\
\text { disabilities }\end{array}$ \\
\hline
\end{tabular}

In the first dimension, the regular student said that he was interested to learn English in an inclusive classroom because the student with disabilities could assume that they were smartest than him. He might think that the student with disabilities had less understanding because the teacher always helped students with disabilities in the learning process or did a task. The students were interested to learn in the inclusive classroom because they had some challenges. The students explained that they had the challenge of competing because every student had different learning potentials. One student might too smart in English while the others were not. Therefore, it was quite hard for students who had less ability to compete with good English students.

Learning English in the inclusive classroom gave more experiences for students to achieve their goals. The students said they had experiences to meet different people. It was because regular students learned with the student with disabilities in the same classroom. Besides learning together, regular students could learn how to interact with the student with disabilities. Learning in an inclusive classroom also developed the student with disabilities' good Behavior. A student with disabilities explained he became more confident interacting with regular students. Regular students also explained that he was confident and aware of speaking with the student with disabilities. The inclusive class helped him understand the kind of people who had disabilities.

One of the student's seatmates with disabilities said that the student with disabilities was disturbing him. It was because the student with disabilities usually cheated on his assignment. Meanwhile, students who were not the student's seatmate with disabilities said that he did not disturb him. It meant that the student with disabilities showed different attitudes depending on the closeness with regular students. In this case, the teacher should pay attention to the student's classroom process with disabilities. The result showed that the student with disabilities' attitude did not influence all regular students' understanding. Most of the regular students stated that student with disabilities did not influence their understanding.

The students expected that there were different attention for the student with disabilities and regular students in inclusive class in the expectation aspect. Both of the students have different needs and potential in learning English. The teacher should be able to manage the material and teaching strategy for the student. Both of the students must get the same opportunity in education even there was different attention in inclusive class. It meant that regular students and students with disabilities learned the same material with the same curriculum.

In the second dimension, 10 regular students said that inclusive education was not new because they have faced it since elementary school or junior high school. Meanwhile, 
21 students said that this was the first time they learned in an inclusive classroom. Students who had the experience to learn in an inclusive classroom could interacting or learning together. In different results, some students who get a new experience felt they needed more time to adapt themselves to the classroom environment. The adaptation was a challenge faced by students to learn in an inclusive classroom. It was related to the learning activity. Especially for the student with disabilities, he found a learning challenge because he learned the same material with regular students.

The teacher's role influenced the implementation of an inclusive classroom. The teacher should have skills and knowledge of how to teach students in an inclusive classroom. A regular student explained that the teacher did not give the same attention to students with disabilities and regular students. The teacher more often gave attention to students with disabilities, especially in doing a task. Meanwhile, the other students explained that the teacher had given all students the same learning process opportunities. It meant that there were some different perceptions among students.

The finding showed that the teacher spent more time with a student with disabilities and needed more time to teach him. It was because the student with disabilities in this classroom was a slow learner. The teachers also spent more time in inclusive education because they used highly controlled and teacher-centered instruction in teaching students in inclusive classes. It is also related to the repetition of the material for the students. The teacher gave more repetition for the student with disabilities because this student was a slow learner. The repetition might disturb other students, but it could help the other students review the material.

In the work setting aspect, 18 students responded that the school facility was sufficient because it was useful, helpful, and students only brought a dictionary from home. Meanwhile, 12 students responded that the school facility was not sufficient for the students because of the availability of packet books and the toilet for students. It could conclude that the facilities were becoming the challenges in implementing inclusive education. The other regular students and students with disabilities also explained it needed a special teacher in inclusive class. The special teacher could handle a student with disabilities when the regular teacher taught regular students.

The student with disabilities explained that he sometimes got bullying by his friend. Some students judge the condition of the student with disabilities as a joke. Meanwhile, the other students explained that the teacher and the students had respected the student with disabilities. Because of this different perception, the teacher should take a role in handling it. Thus, the student with disabilities did not feel he got bullying by his friends. In this situation, the teacher could explain how to interact with the student with disabilities.

\section{The Challenges of Implementing Inclusive Education}

The researcher transcribed all expert students' voices from the interview to show the data in the description. It found several challenges of implementing inclusive education: lack of adaptation with inclusive class, lack of time, lack of facilities, and lack of a special teacher. The first was lacking adaptation with the inclusive classroom. Some regular students had difficulty adapting themselves to learn with the student with disabilities because not all regular students had experience learning together with the student with disabilities.

The second was lacking time. The students in an inclusive classroom sometimes needed more time to understand the material. Especially for the student with disabilities, he needed more than one time to understand the English teacher's explanation. The English teacher usually repeated the material for the student with disabilities. Therefore, the teacher 
should be aware of the time in the learning process because the teacher handled regular students and students with disabilities simultaneously.

The third was lacking facilities. This study showed that the facilities in this school were not sufficient for regular students and students with disabilities. There were some facilities needed, such as LCD, In The Ear (ITE) or Behind The Ear (BTE), and also internet connection (Wi-Fi). The fourth was lacking a special teacher. The special teacher meant the teacher who had the knowledge and ability to teach or handle students with disabilities. Some students stated that the class would be better if a special teacher and regular teacher were in the class.

\section{CONCLUSION}

Based on the findings and discussion in this study, it can conclude that students' perception toward implementing inclusive education was good even though some students had different perceptions in some aspects of perceiver, target or object, and situation. Moreover, the implementation of inclusive education lacked adaptation with inclusive classrooms, time, facilities, and special teachers.

\section{REFERENCES}

Adiputra, S., Mujiyati, \& Hendrowati, T. Y. (2019). Perceptions of Inclusion Education by Parents of Elementary School-Aged Children in Lampung, Indonesia. International Journal Od Instruction, 12(1), 199-212. https://doi.org/https://doi.org/10.29333/iji.2019.12113a

Avcioglu, H. (2017). Classroom Teachers' Behaviors and Peers' Acceptance of Students in Inclusive Classrooms. Educational Sciences: Theory and Practice, 2, 463-492. https://doi.org/10.12738/estp.2017.2.0034

Cohen, L., Manion, L., \& Morrison, K. (1928). Research Methoda in Education (8th ed.). New York: Routledge.

Ediyanto, Atika, I. N., Kawai, N., \& Prabowo, E. (2017). Inclusive Education In Indonesia From The Perspective Of Widyaiswara In Centre For Development And Empowerment Of Teachers And Education Personnel Of Kindergartens And Special Education. Indonesian Journal of Disability Studies (IJDS), 04(02), 104-116.

Khan, K. I., Hashmi, S., \& Khanum, N. (2017). Inclusive Education in Government Primary Schools: Teacher Perceptions. Journal Od Education and Educational Development, $4(1), 32-47$.

Miles, M. B., \& Huberman, A. M. (1994). Qualitative Data Analysis: An Expanded Sourcebook (2nd ed.). United States of America: SAGE Publications.

Okyere, C., Aldersey, H. M., \& Lysaght, R. (2019). The experiences of teachers of children with intellectual and developmental disabilities in inclusive schools in Accra, Ghana. African Journal of Disability, 19(4), 283-294. https://doi.org/10.1111/1471-3802.12447

Permendiknas Nomor 70 Tahun 2009 tentang Pendidikan Inklusif

Rasmitadila, \& Tambunan, A. R. S. (2018). Readiness of General Elementary Schools to Become Inclusive Elementary Schools : A Preliminary Study in Indonesia. International Journal of Special Education, 33(2), 366-381.

Robbins, S. P., \& Judge, T. A. (2013). Organizational Behavior (15th ed.). United Satates of America: Pearson Education.

Schwab, S., Sharma, U., \& Loreman, T. (2018). Are we included? Secondary students' perception of inclusion climate in their schools. Teaching and Teacher Education, 75, 3139. https://doi.org/10.1016/j.tate.2018.05.016

Sunardi, Maryadi, S. (2014). The Effectiveness of a Two-day Inclusion Workshop on 
Cahya Kusuma Negara, Dewa Ayu Eka Agustini, Luh Diah Surya Adnyani

Teachers' Attitudes, Understanding, and Competence in Inclusive Education. World Journal of Education, 4(5), 77-85. https://doi.org/10.5430/wje.v4n5p77

Tahir, K., Brian, D., \& Michael, H. (2019). A Case Study on the Ecology of Inclusive Education in the United States. Journal for Leadership and Instruction, 17-24.

Zhang, Y., Rosen, S., Cheng, L., \& Li, J. (2018). Inclusive Higher Education for Students with Disabilities in China: What Do the University Teachers Think? Higher Education Studies, 8(4), 104-115. https://doi.org/10.5539/hes.v8n4p104 